\title{
Merkel-like cells in the murine conjunctival stroma [version 1;
}

\section{peer review: 1 not approved]}

\author{
Ting Fu ${ }^{1,2 *}$, Yunxia Xue ${ }^{1 *}$, Chaoyong Xia ${ }^{3}$, Yabing Yang ${ }^{1}$, Peng Liu ${ }^{1}$, Jun Liu${ }^{1}$, \\ Wanyu Zhang ${ }^{4}$, Jiansu Chen ${ }^{1,2}$, Yangqiu Li ${ }^{1}$, Dongqing Cai ${ }^{1}$, Zhijie Li ${ }^{1}$
}

\author{
${ }^{1}$ Key Laboratory for Regenerative Medicine, Ministry of Education, Jinan University, Guangzhou, 510632, China \\ 2Institute of Ophthalmology, Medical College, Jinan University, Guangzhou, 510632, China \\ ${ }^{3}$ Department of Histology \& Embryology, Jinan University Medical School, Guangzhou, 510632, China \\ ${ }^{4}$ University of Houston School of Optometry, Houston, TX 77004, USA \\ * Equal contributors
}

V1 First published: 20 Nov 2013, 2:251

https://doi.org/10.12688/f1000research.2-251.v1

Latest published: 20 Nov 2013, 2:251

https://doi.org/10.12688/f1000research.2-251.v1

\section{Abstract}

Merkel cells, discovered by Friedrich Sigmund Merkel in 1875, are found in multiple regions of the skin and some mucosa and make contact with specialized nerve fibers, participating in the perception of touch. However, Merkel cells have thus far not been described on the ocular surface. The purpose of this study was to investigate the distribution and ultrastructure of Merkel cells on the ocular surface and study changes in their number and ultrastructure after corneal epithelial wounding. Entire mouse ocular surfaces were obtained and stained by antibodies and tracking dye on fixed whole-mount specimens. The distribution and ultrastructure of specific fluorescence-positive cells were analyzed using deconvolution microscopy and transmission electron microscopy (TEM), respectively. The corneal epithelial wound-healing model was employed to observe the ultrastructural changes of these CK8-positive cells. We found that CK8-positive cells and FM1-43-positive cells were mainly located in the stromal layer, but not in the epithelial basal layer, of the forniceal conjunctiva. Our TEM results indicate that these cells possess the unique characteristic structures of Merkel cells, including electrondense membrane-surrounded granules and spine-like protrusions of variable lengths, and demonstrate the formation of Merkel cellneurite complexes. After corneal epithelial wounding, these cells exhibited rapid cell shrinkage and nuclear lobulation. Thus, Merkellike cells were found in the conjunctival stroma of the ocular surface and may play an important role in maintaining the normal physiological function of the ocular surface.

Keywords

Merkel cells; Ultrastructure; Conjunctival; CK8; FM1-43

\section{Peer review discontinued \\ Peer review at F1000Research is author- driven. Currently no reviewers are being invited. What does this mean?}

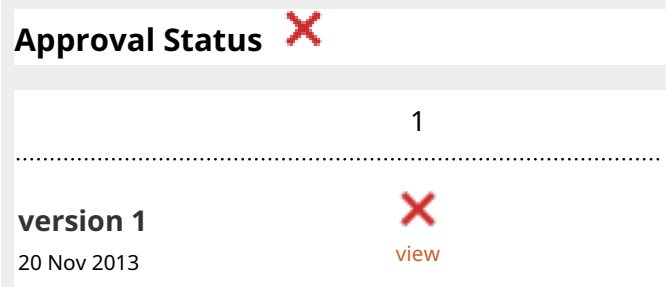

1. Ingrid Moll, University Medical Center Eppendorf, Hamburg, Germany

Any reports and responses or comments on the article can be found at the end of the article. 
Corresponding authors: Chaoyong Xia (cy_xia@tom.com), Zhijie Li (zhijielee@yahoo.com)

Competing interests: No competing interests were disclosed.

Grant information: ZL is funded by National Natural Science Foundation of China grants 39970250, 30772387 and 81070703.

The funders had no role in study design, data collection and analysis, decision to publish, or preparation of the manuscript.

Copyright: @ $2013 \mathrm{Fu}$ T et al. This is an open access article distributed under the terms of the Creative Commons Attribution License, which permits unrestricted use, distribution, and reproduction in any medium, provided the original work is properly cited. Data associated with the article are available under the terms of the Creative Commons Zero "No rights reserved" data waiver (CCO 1.0 Public domain dedication).

How to cite this article: Fu T, Xue Y, Xia C et al. Merkel-like cells in the murine conjunctival stroma [version 1; peer review: 1 not approved] F1000Research 2013, 2:251 https://doi.org/10.12688/f1000research.2-251.v1

First published: 20 Nov 2013, 2:251 https://doi.org/10.12688/f1000research.2-251.v1 


\section{Introduction}

Merkel cells, first described by Fredrich S. Merkel, are mostly located in the basal layer of the epidermis in distinct areas of hairy mammalian skin ${ }^{1}$. Merkel cells have also been shown in vertebrates and cyclostomes ${ }^{2}$ and can be widely found in hairy skin, the eccrine glandular ridges of the glabrous skin (palms and soles), ectodermderived mucosal tissues (palatine mucosa), and whisker pads or taste buds ${ }^{3,4}$. Merkel cells are generally classified into two distinct subpopulations based on whether or not they are associated with nerves. Those that are associated with nerves are referred to as the Merkel cell-nerve complexes and have mechanoreceptive and chemo-sensitive functions. Those that do not associate with nerves possess endocrine functions ${ }^{4-6}$. Recent studies have shown that Merkel cells are important in light-touch responses and can work as neurotransmitters, it is suggested that Merkel cells are essential for the perception of space experienced by individuals 7 .

However, Merkel cells have, thus far, not been described on the ocular surface. In this study, we investigated the distribution and ultrastructure of Merkel cells on the ocular surface and revealed a morphological basis for further study of the function of Merkel cells on the ocular surface.

\section{Materials and methods}

\section{Animals}

Fifty C57BL/6 male mice were approved by the Experimental Animal Center of Sun Yet-Sen University and housed individually in plastic cages $(35 \times 25 \times 15 \mathrm{~cm})$ with sawdust as bedding. Animals were kept at ambient temperature of $25^{\circ} \mathrm{C}$ with $14 \mathrm{~L} / 10 \mathrm{D}$ light cycle, and were offered mice feed and water available ad libitum when they were not undergoing experimentation. All animal procedures were carried out with ethical permission and in accordance with the guidelines described in the Association for Research in Vision and Ophthalmology (ARVO) Statement for the Use of Animals in Vision and Ophthalmic Research and the guidelines of the Animal Experimental Committee at Ji Nan University. All of the mice used in this study were 6-8 weeks old and did not suffer from eye disease.

\section{Whole-mount and immunofluorescence}

Tissue specimens of the entire ocular surfaces, including the cornea and the conjunctiva up to the mucocutaneous junction, were dissected as previously described ${ }^{8}$. In brief, the intact eye was dissected together with the eyelids and fixed with freshly prepared $2 \%$ paraformaldehyde (Beyotime Institute of Biotechnology, China) in PBS. The eyelids were then turned inside out to expose the entire ocular surface. Next, the eye was cut and divided into a superior and an inferior portion. The muscle and other accessory tissues were carefully removed under a stereoscopic microscope (XZ6, Olympus, Japan). Subsequently, the tissue samples were washed in PBS three times, blocked with 2\% BSA (GBC, China) in PBS for 15 minutes at room temperature, and permeabilized with $10 \%$ Triton X-100 (Guoao, China) in 2\% BSA for 15 minutes, prior to incubation with rat anti-mouse Troma- 1 antibody (DSHB, USA, Code No. SP2/0) 1:50 for 48 hours at $4^{\circ} \mathrm{C}$. The tissue samples were then washed in PBS three times, incubated with the secondary FITCDnk Anti-Rat IgG antibody (Jackson ImmunoResearch Laboratories, West Grove, PA, Code No. 712-096-150) 1:100 for 30 minutes, and washed three times again prior to visualization. To flatten the specimen, the eyelids were removed and the specimen was placed epithelial side up and mounted with Fluorescent Mounting Media (Beyotime Institute of Biotechnology, China), which contains 4', 6-diamidino-2-phenylindole (DAPI) (Sigma-Aldrich, Code No. D9564-10MG). The whole-mounts were imaged using the DeltaVision Core system (Applied Precision, USA).

\section{Double immunofluorescence labeling on frozen sections}

The eyes of the mice were dissected as described above, then embedded in optimal cutting temperature (O.C.T) (Sakura Finetek, Japan, Code No. 4583 ), frozen at $-80^{\circ} \mathrm{C}$ in the refrigerator freezer for 30 minutes, and sliced into $5 \mu \mathrm{m}$ thick sections, using a cryostat microtome (Leica, CM1900). The tissue sections were incubated with Troma-1 and FITC-IgG as previously described, and washed in PBS three times, the tissues were stained with mouse anti-mouse Math1 (DSHB, USA, Code No. Atoh1) 1:800, mouse anti-mouse neurogenin 3 (DSHB, USA, Code No. F25A1B3) 1:100 and beta-tubulin III (R\&D, USA, Code No. NL1195R) 1:100 for 24 hours at $4^{\circ} \mathrm{C}$, respectively, then washed in PBS, and incubated with Cy3-Dnk Anti-Mouse IgG (Jackson ImmunoResearch, USA, Code No. 715-165-150) 1:500 antibody for 45 minutes. After washing, the section tissues were mounted with Fluorescent Mounting Media (Beyotime Institute of Biotechnology, China) containing 4', 6-diamidino-2-phenylindole (DAPI) (Sigma-Aldrich, Code No. D9564-10MG). The sections were imaged by fluorescence microscopy (Olympus BX51, Japan).

\section{Transmission electron microscopy examination}

The eyes were dissected together with the eyelids ${ }^{8}$, placed in PBS, and processed as previously described. After separating the eye into a superior and an inferior portion, samples were cut from the cornea to the conjunctiva in $1 \mathrm{~mm}$ segments. A portion of these tissues was fixed in $2.5 \%$ glutaraldehyde (Pelco, USA, Code No. 18426) for 4 hours, washed in PBS three times (each time 15 minutes), then fixed in 1\% osmic acid (Pelco, USA, Code No. 18456) for 15 minutes, after washed in PBS three times, then tissues were dehydrated with a graded ethanol series, consisting of $50 \%, 70 \%, 80 \%, 90 \%$ and $100 \%$ ethanol at 10 minutes each. Tissues were then incubated in a 1:1 mix of 100\% ethanol: Epon812 (Pelco, USA, Code No. 18010) for 2 hours and then rinsed twice with Epon812, for 1 hour each time. Tissues placed onto a mold filled with Epon812. The assembly was inserted into a vacuum chamber and placed in a $60^{\circ} \mathrm{C}$ oven for 24 hours, then tissues were sliced into ultrathin sections with ultramicrotome (LKB2088, Sweden), as required for transmission electron microscopy (TEM) sample preparation ${ }^{5}$. The slices were then stained with 1\% 2\% uranyl acetate (Electron Microscopy Sciences, USA, Code No. 22400) and lead citrate (Sigma, USA, Code No. 6132-043 ). The remaining portion of the tissues was processed according to the method previously described for immunofluorescence, by washing with PBS three times, then similarly processed for TEM but was not stained with uranyl acetate and lead citrate. All of the TEM slices were examined by using a PHILIP5-TECNAI 10 electron microscope (PHILIP5-TECNAI 10, The Netherlands, Philips).

\section{Staining with the FM1-43 dye in vivo}

Twenty mice were intraperitoneally injected with $0.5 \mathrm{ml}$ of FM1-43 (Invitrogen, USA, Code No. F-35355) $(10 \mu \mathrm{g} / \mathrm{ml})$ dissolved in 
high-potassium $(20 \mathrm{mM})$ Hanks' solution (Beyotime Institute of Biotechnology, China) and then euthanized by cervical dislocation after CO2-induced unconsciousness, after 12 hours. To this end, the animals were placed in sealed chambers where carbon dioxide gas is introduced. Once unconsciousness has been achieved and the animals are restrained in a normal standing position on a firm, flat surface and grasped the base of the tail. To produce the dislocation, quickly push forward and down with the hand or object restraining the head. The effectiveness of dislocation can be verified by feeling for a separation of cervical tissues.

The entire ocular surface was immediately separated as previously described and whole-mounted without any further treatment. The FM1-43-positive cells were directly observed using the DeltaVision Core system (Applied Precision, USA).

\section{Corneal epithelial wound model}

Some studies have shown that the membrane potential of Merkel cells changes under stress (i.e., stimulation or changes in osmotic pressure) and can initiate $\mathrm{Ca}^{2+}$ and $\mathrm{K}^{+}$signaling 9 . To determine whether Merkel cells located on the ocular surface respond to stress, we established a corneal epithelial wound model to observe changes in the ultrastructure of these cells. The wound model was applied as previously described ${ }^{10-12}$. Briefly, ten mice were anesthetized by an intraperitoneal injection of pentobarbital sodium (Beyotime Institute of Biotechnology, China) (25-50 mg/kg). The central corneal epithelium was demarcated with a $2 \mathrm{~mm}$ trephine and removed using a diamond blade for refractive surgery (Accutome, Malvern, PA) under a stereoscopic microscope (XZ6, Olympus, Japan). Care was taken to minimize any injury to the epithelial basement membrane and stroma. Twenty-four hours after wounding, the specimen tissues were processed as described above ${ }^{8}$, fixed, sectioned, stained, and analyzed ${ }^{5}$. Finally mice were euthanized by cervical dislocation after $\mathrm{CO} 2$-induced unconciousness.

\section{Results}

As previously reported, Merkel cells express CK $8^{4}$. In this study, we first identified the location of CK8-positive cells on the ocular surface. The ocular surface whole-mounts show that CK8-positive cells were localized in the fornix and the palpebral conjunctiva, and CK8-positive immunofluorescence was observed in the membrane, nucleus and cytoplasm of specific cells. We also found that the CK8-positive cells exhibited circular nuclei and visible nucleoli, and the cytoplasmic fluorescence revealed reticular and granular shapes (Figure 1). However, we did not find any CK8immunofluorescence-positive cells in the bulbar conjunctiva.

Double immunofluorescence stain showed that there were two kinds of CK8-positive cells on the ocular surface. The types that also stained with Math1 (Figure 2) were located in the stromal layer of the fornix and the palpebral conjunctiva, the other in the epithelial basal layer (we also identified that the CK8-positive cells in the epithelial basal layer were goblet cells). So we speculated that the Merkel cells were located in the stromal layer and could express Ngn3 (Figure 3) and beta-tubulin III (Figure 4) in the cytoplasm.

The classical method to identify Merkel cells has been electron microscopy, so we used TEM to analyze the ultrastructure of the conjunctival cells. As shown in Figure 5, there is a class of cells contain electron-dense membrane-surrounded granules, mitochondria and intermediate filaments (Figure 5A). In addition, these cells exhibited spine-like protrusions of variable lengths from the cell surface (Figure 5B) and located in the conjunctival stroma (Figure 5C). These characteristics are similar to the ultrastructural features of Merkel cells ${ }^{4}$. The granules were not only observed within these cells (Figure 5A) but were also found in the extracellular regions (Figure 5B). We also observed some cells that were associated with nerve terminals, forming Merkel cell-neurite complexes with vesicles at the nerve endings (Figure 5D). Shrinkage of the membranesurrounded granules and Merkel cells in close proximity to the conjunctival epithelium and nuclear lobulation were investigated after corneal wounding (Figure 5E). CK8-specific Merkel cells were observed in the conjunctival stroma by immuno-electron microscopy (Figure 5F). A small number of CK8-specific particles were observed in the conjunctival epithelium cells under high magnification (Dataset-1).

It has been reported that the FM1-43 dye is a useful marker for live Merkel cells ${ }^{13}$. Therefore, we used FM1-43 dye to identify conjunctival Merkel cells. Twelve hours after intraperitoneal injection of FM1-43, green fluorescent granules were observed in the cytoplasm of Merkel cells, and nuclear labeling was found in the conjunctiva of the stroma using the deconvolution microscopy (Figure 1B).

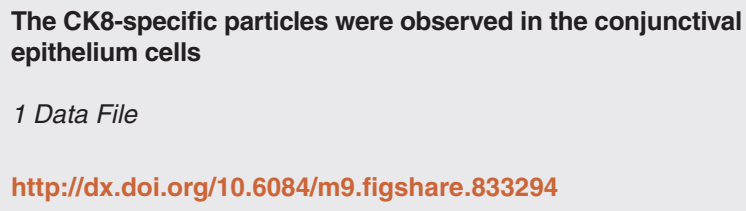

\section{Discussion}

The conjunctiva is an important part of the ocular surface. It plays a very important role in the process of mucus secretion and immunological reactions. The conjunctiva can be divided into two parts, the conjunctival epithelium and the stroma. The epithelial cells can be further classified into superficial cells, intermediate cells and basal cells $\mathrm{s}^{14}$. The conjunctiva, similar to the skin and some mucosal tissues, is developmentally derived from the ectoderm. Previous studies have shown that Merkel cells are located in the epithelia of the skin and in the oral mucosa, where they participate in endocrine and mechanoreceptor functions ${ }^{3,4}$. However, their presence on the ocular surface had not yet been confirmed.

The classical method used to identify Merkel cells is to check for their ultrastructure using TEM. Recently, various studies have confirmed that Merkel cells express specific cytokeratins (CK), such as CK8, CK18, CK19, and CK20 $0^{15-17}$, and neuropeptides, such as vasoactive intestinal peptide (VIP) ${ }^{18}$, substance $\mathrm{P}^{19}$ and calcitonin generelated peptide (CGRP) ${ }^{20}$, and other proteins, such as Math1, neurofilament-H, and neurotrophin- $3^{3}$. These bio-markers provide a basis for the identification of Merkel cells using light microscopy. Currently, there are two hypotheses for the origin of Merkel cells: one suggests that Merkel cells differentiate from epidermal keratinocyte-like cells and the other states that Merkel cells arise from stem cells of neural crest origin that migrated during embryogenesis ${ }^{3,4}$. 


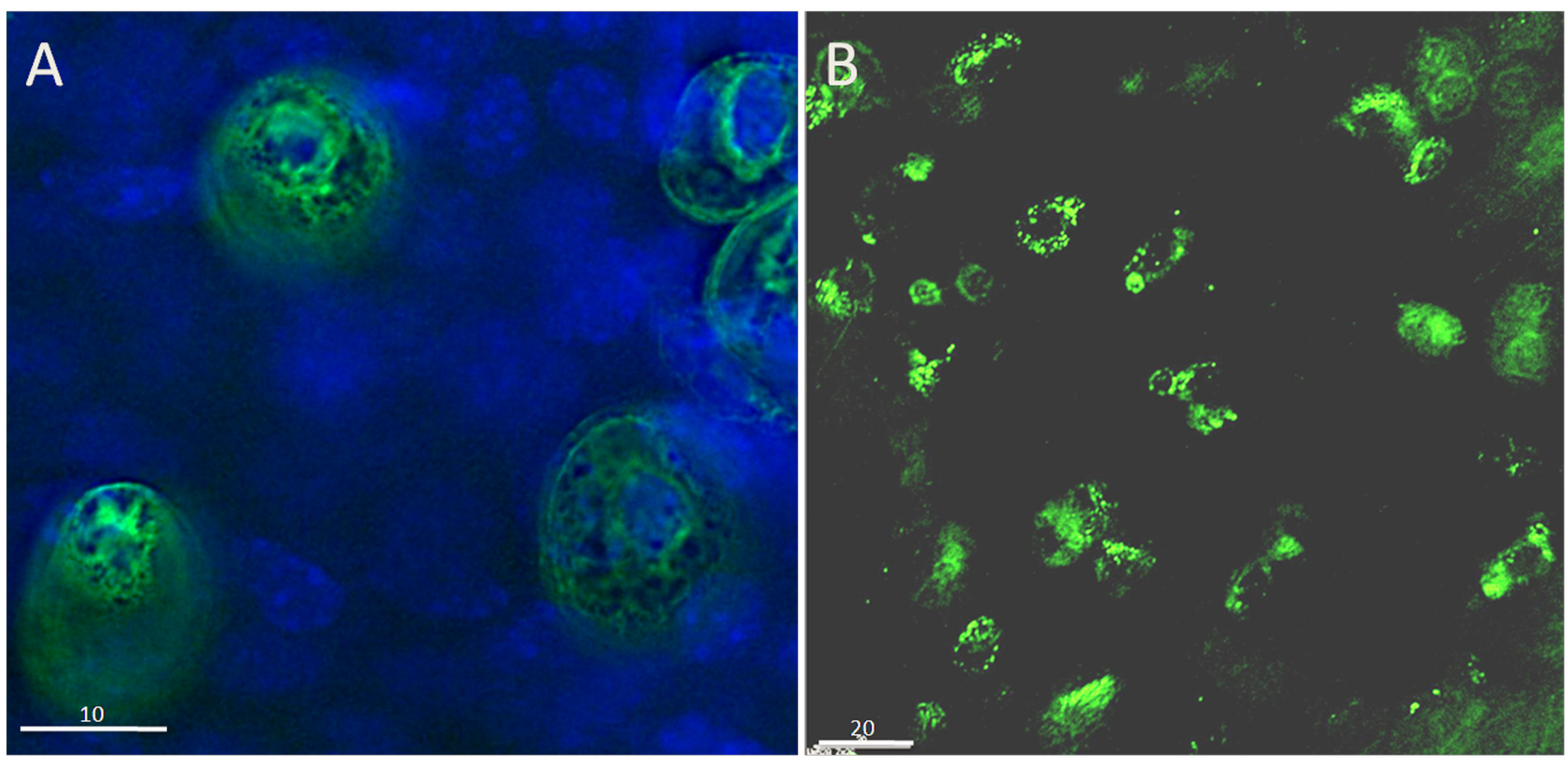

Figure 1. Merkel cells were observed by deconvolution microscopy. (A) CK8-positive cells (green). The CK8-positive immunofluorescence was observed in the membrane, nucleus and cytoplasm of specific cells, and the cytoplasmic fluorescence revealed reticular and granular shapes. (B) Merkel cells incorporated FM1-43 dye. The green fluorescent granules were observed in the cytoplasm of Merkel cells.

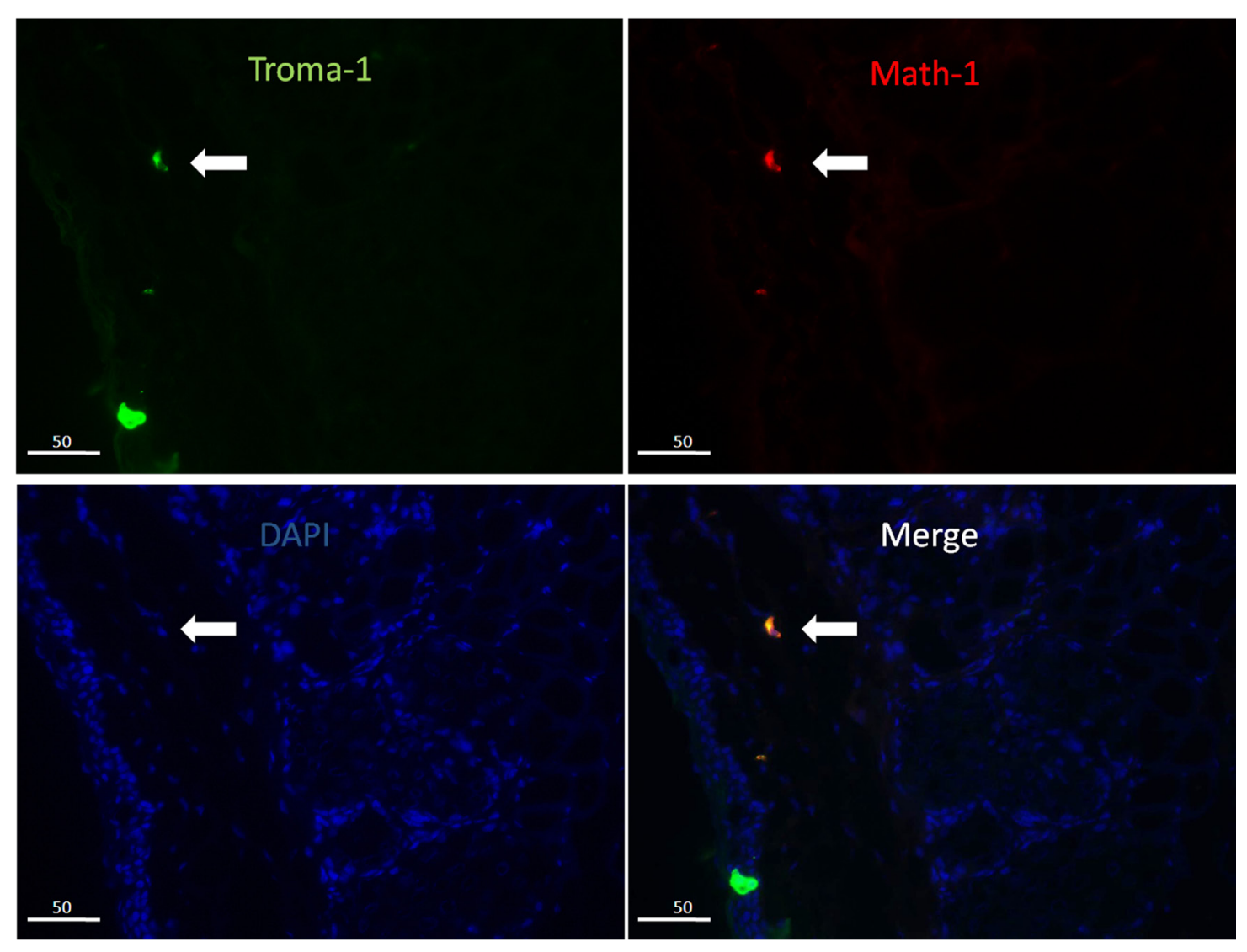

Figure 2. Troma-1 and Math-1 double immunofluorescence stain. The CK8-positive cells (green) also express Math-1 (red) in the cytoplasm. 


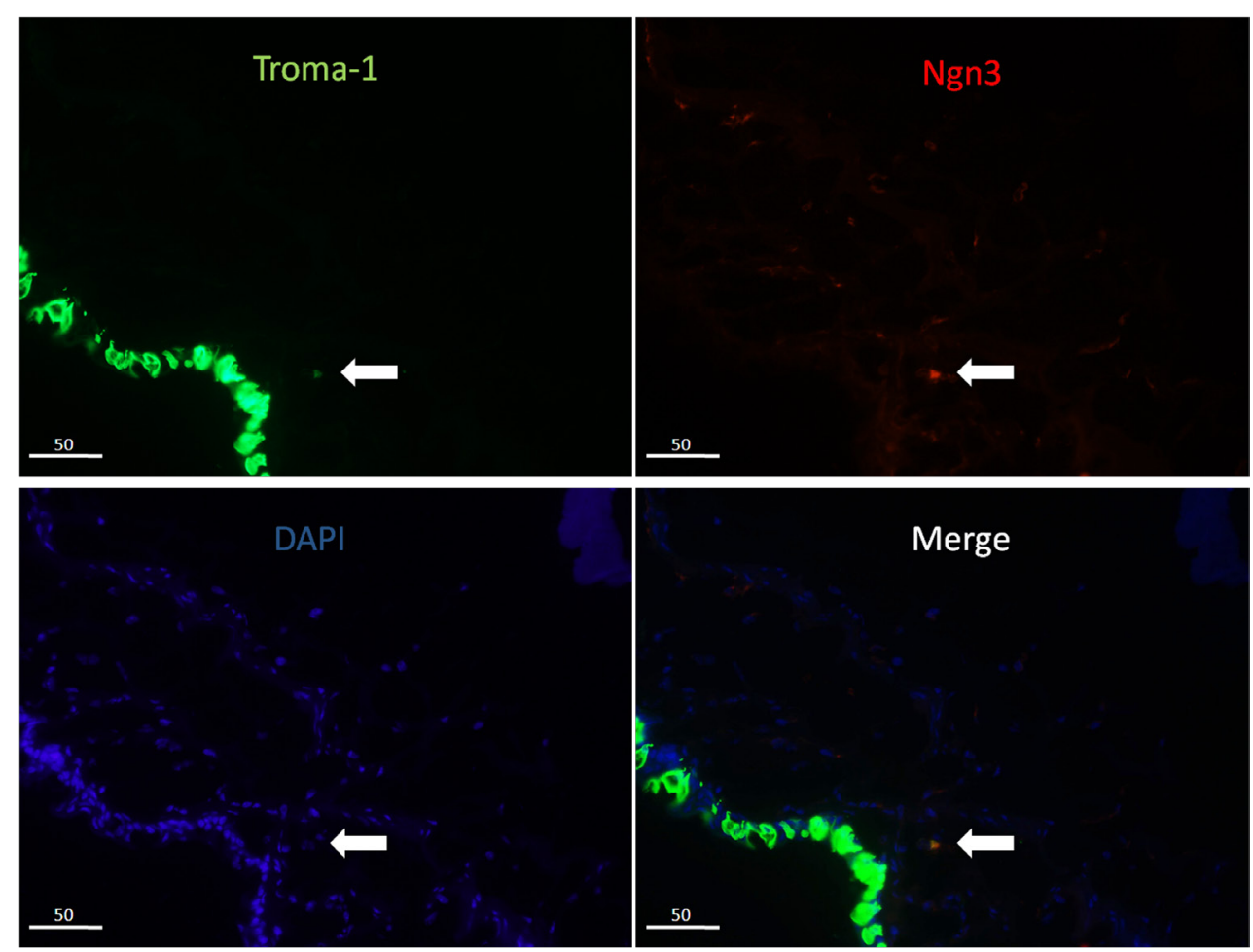

Figure 3. Troma-1 and Ngn3 double immunofluorescence stain. The CK8-positive cells (green), in the stroma, can express Ngn3 (red) in the cytoplasm, but the CK8-positive cells in the epithelial layer did not express Ngn3.

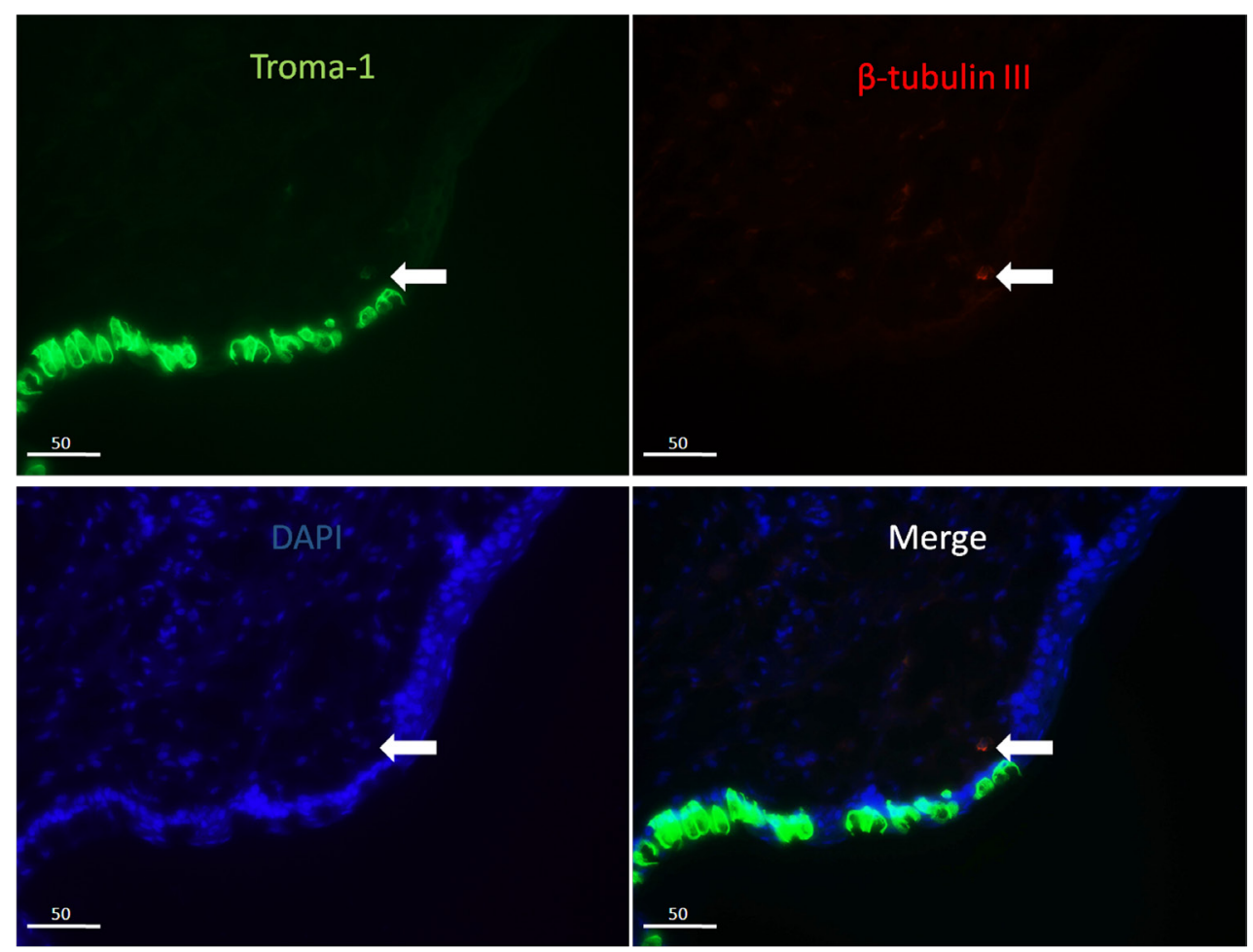

Figure 4. Troma-1 and beta-tubulin III double immunofluorescence stain. The CK8-positive cells (green) in the stroma express betatubulin III (red), but the CK8-positive cells in the epithelial layer did not express beta-tubulin III. 

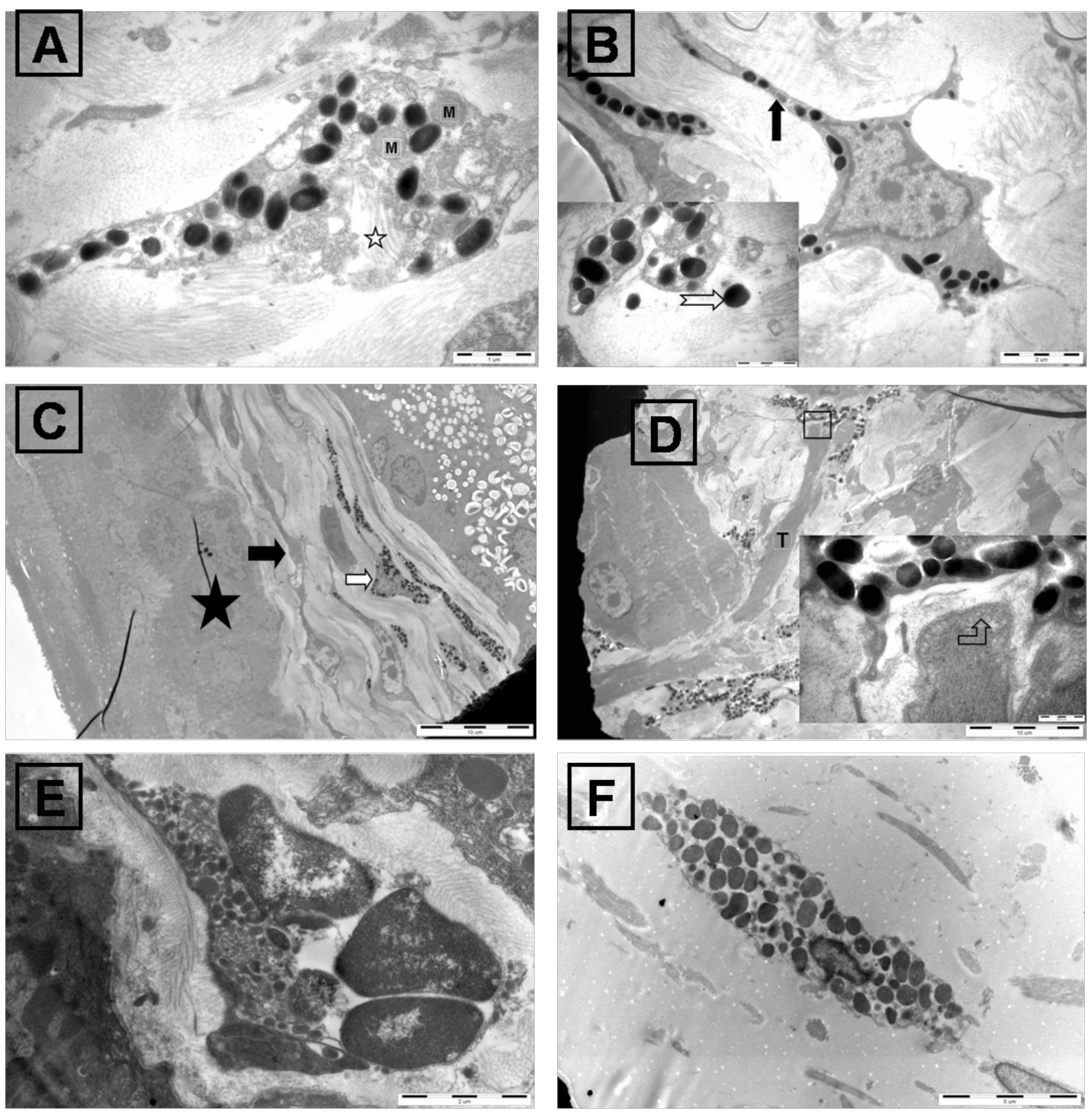

Figure 5. Ultrastructure of the Merkel cells. (A) Merkel cells contain mitochondria (M) and intermediate filaments (indicated by a star); bar:1 $\mu \mathrm{m}$. (B) Merkel cells exhibited spine-like protrusions of variable lengths (indicated by black arrow); bar: $2 \mu \mathrm{m}$, and electron-dense membrane-surrounded granules (indicated by white arrow) can been seen in the extracellular regions; bar: $1 \mu \mathrm{m}$. (C) Merkel cells (indicated by white arrow) and myofibroblast (indicated by black arrow) located in the stroma of the conjunctiva. Conjunctival epithelium was indicated by

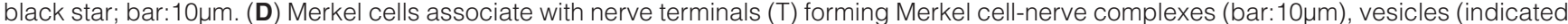

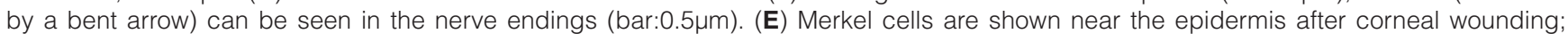

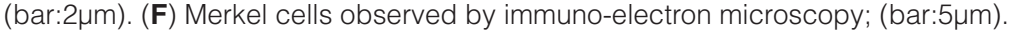


In this study, we observed Merkel cells located at the bottom of the basal adjacent stroma in the fornix and the palpebral conjunctiva and the cells could be stained with CK8, Math1, Ngn3 and betatubulin III. This suggests that the Merkel cells in the conjunctival might originate from the neural crest.

The ultrastructure of Merkel cells in the conjunctival stroma exhibits characteristics similar to those of other tissues, such as an electrondense core with membrane-surrounded granules and intermediate filaments (Figure 5C). They have spine-like protrusions of variable lengths (Figure 5B) $)^{1,4,21}$, and some Merkel cells make contact with nerve terminals to form Merkel cell-neurite complexes (Figure 5D). The conjunctival Merkel cells, however, also have unique features, as they are distributed in the conjunctival stroma and were not associated with keratinocytes (Figure 5A, B). In addition, their granules can be visualized not only within the cells (Figure 5A) but also in extracellular regions (Figure 5B).

The technique of marking live Merkel cells with quinacrine has been employed to differentiate these cells from other epidermal cells in vitro and in vivo. However, the quinacrine dye incorporated by Merkel cells is rapidly lost, thus making the fluorescence very difficult to identify ${ }^{22-24}$. Another important reason that chloroquine is no longer used is due to the agent's severe toxicity to the optic nerve. Fukuda et al. ${ }^{13}$ examined the absorption of FM dyes in Merkel cell cultures and found that FM dyes produce a specific fluorescence that remains sufficiently long to allow for clear identification of Merkel cells. The FM1-43 dye exhibited the best effects as compared with other FM dyes. Our results showed that an intraperitoneal injection of FM1-43 could effectively label the conjunctival stromal Merkel cells in vivo, which may be a useful technique for future studies of Merkel cells.

There is still some controversy regarding the function of Merkel cells. In vitro, neuropeptides secreted from Merkel cells (e.g., VIP and substance P) can promote cell growth and differentiation of keratinocytes and fibroblasts. These neurosecretory substances are released from the Merkel cells and act as neurotransmitters in the Merkel cell-axon complexes ${ }^{4}$. However, the exact function of Merkel cells in the conjunctiva stroma is still unclear. Thus, we established a corneal abrasion model to observe the response of these cells to stress. In this study, we demonstrated that wounding the corneal epithelium can induce nuclear lobulation, and shrinkage of cell-volume and an increase in the membrane-surrounded granules of Merkel cells (Figure 5E). These results indicate that Merkel cells in the conjunctival stroma might play an important physiological and pathological role in the stress response of corneal epithelium wounding. Further research work about the functions of the cells is ongoing in our laboratory.

\section{Conclusions}

In conclusion, our data showed that Merkel cells are mainly present in the conjunctival stroma, with the following findings: (1) The cells are distributed in the forniceal conjunctival stroma. (2) The Merkel cells express CK8, Math1, Ngn3 and $\beta$-tubulin III. (3) The ultrastructure of the Merkel cells contains an electron-dense core with membrane-surrounded granules, intermediate filaments and mitochondria. (4) Some Merkel cells make contact with nerve terminals to form Merkel cell-neurite complexes. (5) The cells exhibit endocytosis of FM1-43. (6) After corneal epithelial wounding, nuclear lobulation, shrinkage of cell-volume, and an increase in the membrane-surrounded granules of the Merkel cells was also observed. However, further studies are needed to verify the exactly physiological function and role of these cells in specific ocular surface diseases.

\section{Author contributions}

TF, YX, and CX performed histological analysis, data analysis, imaging and co-wrote the manuscript. TF, YX, YY, PL and JL conducted the animal experiments. WZ, JC, YL, and DC contributed data analysis. ZL designed the study, supervised experiments, analyzed data and wrote the final manuscript.

\section{Competing interests}

No competing interests were disclosed.

\section{Grant information}

ZL is funded by National Natural Science Foundation of China grants 39970250, 30772387 and 81070703.

The funders had no role in study design, data collection and analysis, decision to publish, or preparation of the manuscript.
1. Halata Z, Grim M, Bauman KI: Friedrich Sigmund Merkel and his "Merkel cell", morphology, development, and physiology: review and new results.

Anat Rec A Discov Mol Cell Evol Biol. 2003; 271(1): 225-39.

PubMed Abstract | Publisher Full Text

2. Tachibana T, Nawa T: Recent progress in studies on Merkel cell biology. Anat Sci Int. 2002; 77(1): 26-33.

PubMed Abstract | Publisher Full Text

3. Boulais N, Misery L: Merkel cells. J Am Acad Dermatol. 2007; 57(1): 147-65. PubMed Abstract | Publisher Full Text

4. Moll I, Roessler M, Brandner JM, et al.: Human Merkel cells--aspects of cell biology, distribution and functions. Eur J Cell Biol. 2005; 84(2-3): 259-71. PubMed Abstract | Publisher Full Text

5. Yin J, Wang $\mathrm{H}$, Racey P, et al.: Distribution and ultrastructure of Merkel cell of the fishing bat (Myotis ricketti). Sci China C Life Sci./Chinese Academy of Sciences. 2009; 52(9): 802-6.

PubMed Abstract | Publisher Full Text

6. Lucarz A, Brand G: Current considerations about Merkel cells. Eur J Cell Biol. 2007; 86(5): 243-51. PubMed Abstract | Publisher Full Text

7. Maricich SM, Wellnitz SA, Nelson AM, et al:: Merkel cells are essential for light-touch responses. Science. 2009; 324(5934): 1580-2. PubMed Abstract | Publisher Full Text | Free Full Text

8. Nagasaki T, Zhao J: Uniform distribution of epithelial stem cells in the bulbar conjunctiva. Invest Ophthalmol Vis Sci. 2005; 46(1): 126-32. PubMed Abstract | Publisher Full Text

9. Boulais N, Pennec JP, Lebonvallet N, et al.: Rat Merkel cells are 
mechanoreceptors and osmoreceptors. PLOS One. 2009; 4(11): e7759. PubMed Abstract | Publisher Full Text | Free Full Text

10. Li Z, Burns AR, Miller SB, et al.: CCL20, gammadelta T cells, and IL-22 in corneal epithelial healing. FASEB J. : official publication of the Federation of American Societies for Experimental Biology. 2011; 25(8): 2659-68. PubMed Abstract | Publisher Full Text | Free Full Text

11. Liu Q, Smith $\mathrm{CW}$, Zhang W, et al:: NK cells modulate the inflammatory response to corneal epithelial abrasion and thereby support wound healing. Am J Pathol. 2012; 181(2): 452-62.

PubMed Abstract | Publisher Full Text | Free Full Text

12. Li Z, Burns AR, Han L, et al.: IL-17 and VEGF are necessary for efficient corneal nerve regeneration. Am J Pathol. 2011; 178(3): 1106-16.

PubMed Abstract | Publisher Full Text | Free Full Text

13. Fukuda J, Ishimine $H$, Masaki $Y$ : Long-term staining of live Merkel cells with FM dyes. Cell Tissue Res. 2003; 311(3): 325-32. PubMed Abstract | Publisher Full Text

14. Zhu WQ, Xu JJ, Sun XH, et al:: [Normal human bulbar conjunctiva on confocal microscopy in vivo]. Zhonghua yan ke za zhi. Chinese journal of ophthalmology. 2009; 45(4): 344-9. PubMed Abstract

15. Moll R, Moll I, Wiest W: Changes in the pattern of cytokeratin polypeptides in epidermis and hair follicles during skin development in human fetuses. Differentiation; research in biological diversity. 1982; 23(2): 170-8. PubMed Abstract | Publisher Full Text

16. Moll R, Moll I, Franke WW: Identification of Merkel cells in human skin by specific cytokeratin antibodies: changes of cell density and distribution in fetal and adult plantar epidermis. Differentiation; research in biological diversity. 1984; 28(2): 136-54.

PubMed Abstract | Publisher Full Text

17. Saurat $\mathrm{JH}$, Didierjean $\mathrm{L}$, Skalli $\mathrm{O}$, et al.: The intermediate filament proteins of rabbit normal epidermal Merkel cells are cytokeratins. $J$ Invest Dermatol. 1984; 83(6): 431-5

PubMed Abstract | Publisher Full Text

18. Hartschuh W, Weihe E, Yanaihara N: Immunohistochemical analysis of chromogranin A and multiple peptides in the mammalian Merkel cell: further evidence for its paraneuronal function? Arch Histol Cytol. 1989; 52(Suppl): 423-31.

PubMed Abstract | Publisher Full Text

19. Katayama I, Nishioka K: Substance $P$ augments fibrogenic cytokine-induced fibroblast proliferation: possible involvement of neuropeptide in tissue fibrosis. J Dermatol Sci. 1997; 15(3): 201-6.

PubMed Abstract | Publisher Full Text

20. Kvetnoy IM, Reiter RJ, Khavinson VK: Letter to the Editor. Claude Bernard was right: hormones may be produced by "non-endocrine" cells.

Neuro Endocrinol Lett. 2000; 21(3): 173-4.

PubMed Abstract

21. Winkelmann RK, Breathnach AS: The Merkel cell. J Invest Dermatol. 1973; 60(1): 2-15.

PubMed Abstract

22. Nurse CA, Mearow KM, Holmes M, et al:: Merkel cell distribution in the epidermis as determined by quinacrine fluorescence. Cell Tissue Res. 1983; 228(3): 511-24.

PubMed Abstract | Publisher Full Text

23. Yamashita $\mathrm{Y}$, Akaike $\mathrm{N}$, Wakamori M, et al.: Voltage-dependent currents in isolated single Merkel cells of rats. J Physiol. 1992; 450: 143-62. PubMed Abstract | Free Full Text

24. Yamashita $\mathrm{Y}$, Toida $\mathrm{K}$, Ogawa $\mathrm{H}$ : Observation of Merkel cells with scanning electron microscopy. Neurosci Lett. 1993; 159(1-2): 155-8.

PubMed Abstract | Publisher Full Text 


\section{Peer review discontinued Peer review at F1000Research is author-driven. Currently no reviewers are being invited. What does this mean?}

\section{Version 1}

Reviewer Report 07 March 2014

https://doi.org/10.5256/f1000research.2392.r3465

(C) 2014 Moll I. This is an open access peer review report distributed under the terms of the Creative Commons Attribution License, which permits unrestricted use, distribution, and reproduction in any medium, provided the original work is properly cited.

\section{Ingrid Moll}

Department for Dermatology and Venerology, University Medical Center Eppendorf, Hamburg, Germany

This paper deals with Merkel-like cells in the murine conjunctival stroma, claimed to be identified by immunofluorescence microscopy, incorporating TM1-43 dye and by electron microscopy. I have various points of criticism and doubts about the nature of the identified cells:

1. Fig. 1:

$\mathrm{C}$ (Keratin) 8 immunofluorescence staining is stated to have been located in the membrane, nucleus and cytoplasm of the specific cells. However, CK 8 in murine Merkel cells is restricted to the very typical cytoskeleton within the cytoplasm. Moreover, CK 8 can be found in many organs not restricted to Merkel cells and therefore the more specific staining for CK 20 should be used to identify Merkel cells in general.

\section{Fig. 2:}

The TROMA-1 antibody staining remains unclear, most probably the nucleus is stained (see DAPI), but TROMA-1 should again, decorate the cytoskeleton.

\section{Fig. 3:}

The TROMA-1-antibody decorates a cell layer and this cell layer is not decorated by the Ngn3 antibody. Again, cytokeratin 20 should be used to identify Merkel cells.

4. Fig. 4:

The same is true for this figure (see Fig. 3).

5. Electron microscopy: the particles stated as being neuroendocrine granules are up to $1 \mu \mathrm{m} /$ in diameter. However, the neuroendocrine granules of Merkel cells show a diameter 80-120nm and a typical dense cored structure. Therefore, the particles shown could not represent dense cored neuroendocrine granules and thus the cells are not Merkel cells.

Competing Interests: No competing interests were disclosed. 
I confirm that I have read this submission and believe that I have an appropriate level of expertise to state that I do not consider it to be of an acceptable scientific standard, for reasons outlined above.

The benefits of publishing with F1000Research:

- Your article is published within days, with no editorial bias

- You can publish traditional articles, null/negative results, case reports, data notes and more

- The peer review process is transparent and collaborative

- Your article is indexed in PubMed after passing peer review

- Dedicated customer support at every stage

For pre-submission enquiries, contact research@f1000.com 